\title{
TRACE ELEMENTS AND Pb ISOTOPE VARIATIONS IN GALENA FROM THE ONÇA GOLD DEPOSIT, MATO GROSSO, BRAZIL: FLUID MIXING FROM HYDROTHERMAL AND CRUSTAL SOURCES
}

\author{
M.C.Geraldes ${ }^{1}$; L.A.Petronilho ${ }^{2}$; D.Silva ${ }^{3}$
}

PALAVRAS-CHAVE: gold, isotopes, mineral chemistry, hydrothermal solutions.

GERALDES, M.C. et al. (1996) Trace elements and $\mathrm{Pb}$ isotope variations in galena from the Onça gold deposit, Mato Grosso, Brazil: fluid mixing from hydrothermal and crustal sources. Bol.IG-USP, Sér.Cient., 27:81-98.

\begin{abstract}
This study deals with the petrography of sulfides and quartz veins, $\mathrm{Pb}$ isotopes, major and trace elements in galena, microthermometry and Raman spectrometry of fluid inclusions, with the objective of delineating temporal and spatial aspects of the fluid circulation patterns during the origin of the Onça gold deposit, Mato Grosso State, Brazil.

The $\mathrm{Pb}$ isotope and mineral chemistry data indicate variable sources for the $\mathrm{Pb}$ isotopes, major $(\mathrm{S}$ and $\mathrm{Pb})$ and trace elements $(\mathrm{Sb}, \mathrm{Ag}, \mathrm{Zn}$ and $\mathrm{Se}$ ), with increases or decreases of the contents during the growth of the galena crystals. The results suggest that the variation may be due to the contamination of the hydrothermal solution by mixing with components derived from supracrustal host rocks of Pontes e Lacerda metavolcanic-sedimentary sequence.

The mineral chemistry and fluids inclusion studies suggest two possible sources for the hydrothermal solutions: (1) deep solutions that originated during the regional metamorphism represented by the Aguapei metamorphic event where the solutions present aqueous-carbonic composition and low salinity. Geologic control of the mineralization is in agreement with this hypothesis because the ore bodies are syntectonic with foliation formed during the Aguapef event; (2) high contents of base metals indicates a plutonic influence in the origin of the fluids. Geologic controls also are in agreement with this hypothesis because pegmatitic intrusion was synchronous with the mineralizations.

The $\mathrm{Pb}$ isotope and fluid inclusion relations allows the conclusions that the compositions of the hydrothermal solutes were variable during the emplacement of the quartz veins and the growth of galena crystals. The earlier solutes had hydrocarbons and were more radiogenic, whereas the later solutes had base metals and were less radiogenic.

The Onça deposit originated during a metamorphic event by the effect of hydrothermal solutions related to plutonism, and with an important contribution from the host rocks as recorded by the influence of isotope, major and trace element compositions on the growth of ore-forming minerals.
\end{abstract}

\footnotetext{
IInstituto de Geociências/UNICAMP, São Paulo, Brasil. Actual address: Departamento de Geologia Geral, Instituto de Geociências/USP, Săo Paulo, Brasil. E-mail: mcgeral@usp.br.

${ }^{2}$ Centro de Pesquisas Geocronológicas, Instituto de Geociências/USP, São Paulo, Brasil.

'DMG, Instituto de Geociências/UNICAMP, São Paulo, Brasil.
} 


\section{RESUMO}

Este estudo compreende petrografia de sulfetos e veios de quartzo, elementos traços, maiores e isótopos de $\mathrm{Pb}$ em galena, microtermometria e espectrometria Raman em inclusões fluidas com o objetivo de delinear aspectos temporais e espaciais da circulação de fluidos durante a origem do depósito aurifero do Onça, Estado do Mato Grosso.

Os resultados de isótopos de $\mathrm{Pb}$ e a química mineral indicam uma fonte variável para os isótopos de $\mathrm{Pb}$ e para elementos maiores ( $\mathrm{S} \mathrm{e} \mathrm{Pb}$ ) e elementos traços ( $\mathrm{Sb}, \mathrm{Ag}, \mathrm{Zn}$ e $\mathrm{Se}$ ) com aumentos e diminuiçōes nos seus conteúdos durante o crescimento dos cristais de galena de forma que esta variação pode ser resultado da contaminação da soluçāo hidrotermal pelas rochas supracrustais encaixantes da Sequência Metavulcano-sedimentar Pontes e Lacerda.

A quimica mineral e o estudo das inclusбes fluidas sugerem dois tipos de fontes para as soluçōes hidrotermais: (1) soluçōes originadas em profundidade durante o metamorfismo regional representado pelo evento Aguapei, com soluçōes aquocarbônicas e de baixa salinidade, hipótese corroborada pela concordância dos corpos de minério com a foliação regional gerada por este evento; (2) altos valores de metais básicos indicam uma influência plutônica na origem dos fluidos.

Os isótopos de $\mathrm{Pb}$ e os estudos de inclusōes fluidas analisadas conjuntamente permitem concluir que a composição das soluçōes hidrotermais foram variáveis durante o emplacement dos veios de quartzo e o crescimento dos cristais de galena. As soluçōes iniciais apresentam $\mathrm{CH}_{4}$ na sua composiçăo e são mais radiogênicas. As soluçōes finais apresentam metais básicos em sua composição e săo menos radiogênicos.

Como conclusăo é possivel sugerir que o depósito do Onça foi originado durante um evento metamórfico por soluçōes hidrotermais com influência de plutonismo, com uma importante contribuição das rochas encaixantes na composição isotópica do $\mathrm{Pb}$, nos elementos maiores e traços durante 0 crescimento dos minerais de minério.

\section{INTRODUCTION}

$\mathrm{Pb}$ isotope determinations in oreforming minerals are particularly useful when they can be directly combined with petrological, geochemical and fluid inclusions studies. In addition to dating of trace phases, radiogenic isotope study of ore deposits can potentially provide information on the source of solutes. Similarly, ore-forming mineral geochemistry and fluid inclusions may explicitly constrain the crustal or mantle reservoirs that are sampled by the oreforming system (DeWolf et al., 1993; Frei \& Kamber, 1995).

$\mathrm{Pb}$ isotope source tracing relies on a number of assumptions, including: (1) measured or calculated initial ratios corresponding to the isotopic composition of the ore-forming hydrothermal system; (2) fluid signatures that accurately reflect the isotopic composition of the rock reservoir(s) sampled by the hydrothermal system, and (3) contemporane- ous isotopic ratios of all possible reservoirs (Kerrich, 1991; Faure, 1986). Moreover, many studies have shown that $\mathrm{Pb}$ isotope of ore deposits may be a mixture (Peucker-Ehrenbrink et al., 1994) of hydrothermal contributions (Deloule et al., 1983; Bierlein et al., 1996) and $\mathrm{Pb}$ indigenous to the adjacent host rocks (Croceti et al., 1988; Wilton, 1991; Sundblad et al., 1991) or from a pre-existing deposit (Tassinari et al., 1990).

On the other hand, the $\mathrm{Pb}$-isotopic data of ore-forming minerals may indicate derivation of mineralizing fluids associated with the hydrothermal circulation generated by local igneous bodies intruded during the ore-forming process (Duane et al., 1991; Deloule et al., 1989). Most studies assume that mineral or minerals generated by this process are isotopically homogeneous and may have some variations if enriched in ra- 
diogenic $\mathrm{Pb}$ from $\mathrm{U}$ and $\mathrm{Th}$ radioactive decay (Yuxue et al., 1995). However Hart et al. (1981) demonstrated that galena may show concentric zonation of $\mathrm{Pb}$ isotopes with total variation of $\pm 3 \%$ in ${ }^{208} \mathrm{~Pb} /{ }^{204} \mathrm{~Pb}$ and $4 \%$ in ${ }^{206} \mathrm{~Pb} /{ }^{204} \mathrm{~Pb}$ and the range in the observed $\mathrm{Pb}$ isotope $\mathrm{ra}-$ tios in the crystal is larger than that observed previously for bulk galena analysis from throughout the Mississippi Valley base metal deposits (Cannon et al., 1963). $\mathrm{Pb}$ isotope zoning in pyrite was also described in the literature (Raymond, 1996).

The application of major and trace element, and isotopic composition of galena and fluid inclusion data are useful in delineating temporal and spatial aspects of the fluid circulation patterns and are used here to interpret the origin of the Onça gold deposit, Mato Grosso State, Brazil.

\section{GEOLOGIC SETTING}

The gold deposits of the Pontes e Lacerda region are situated in the SW part of the Amazon Craton (Fig. 1) within the Aguapei-Sunsás mobile belt, a N-NW trending zone time-related to Grenvillian folded rocks (Fig. 2). Present knowledge about the evolution of the study area was done by Sadowski \& Bettencourt (1996). The geological units which outcrop in the region include the Basal Complex granulites and gneissicmigmatitic rocks, probably correlated to the 1961 Ma old Lomas Maneches Granulite Complex (Litherland et al., 1989); the Pontes e Lacerda metavolcanic-metasedimentary sequence (MVSS) (1921 Ma, Geraldes et al., 1996a) probably equivalent to the Alto Jauru greenstone belt to the east of the study area (1988 Ma, Monteiro et al., 1986; Geraldes et al., 1996a); the Santa Helena granite gneiss (gneissification at around $1300 \mathrm{Ma}$, Menezes et al., 1993; Geraldes et al., 1996a); the Maraboa

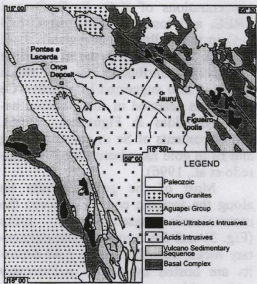

Figure 1 - Localization of Onça Gold Deposit with regional geologv.

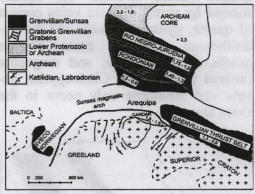

Figure 2 - Tectonic model fit of the Laurentia Amazonia (Sadowiski \& Bettencourt, 1996).

granite (1257 Ma, Geraldes et al., 1996a); the clastic metasedimentary rocks of the Aguapei Group which is equivalent to the Bolivian Sunsás Group (1300-950 Ma, Litherland et al., 1989) and, the Rio Cagado Suite of unknown age which outcrops concordantly with the Aguapei thrust zone and is considered to be syntectonic to the AguapeiSunsás event.

In the mineralized zones, hydrothermal processes provided enhanced 
concentrations of $\mathrm{K}_{2} \mathrm{O}, \mathrm{F}, \mathrm{Fe}_{2} \mathrm{O}_{3}$ and LREE, and losses of $\mathrm{CaO}, \mathrm{MgO}$ and $\mathrm{FeO}$ in the wallrocks. In general, these changes were related to a probable magmatic contribution to the fluids which is also suggested by positive $\mathrm{Ce}$ anomalies detected in some altered basalts (Geraldes \& Figueiredo, 1996). Minor contents of $\mathrm{Se}$ in pyrite and, $\mathrm{Ag}$ and $\mathrm{Bi}$ in gold have been found (Figueiredo et al., 1996).

Most of the gold deposits lie along the tectonic contact between the metavolcanic-metasedimentary rocks (Fig. 3) and the Aguapei metasedimentary rocks. Secondly, some gold deposits are hosted by clastic sedimentary rocks, schists and granitoids. Disseminated and vein controlled mineralization are commonly found in volcanic host rocks whereas sedimentary rock or granite hosted deposits are mainly formed by veins. The ore veins consist of quartz, pyrite and gold, and the hydrothermal alteration zones contain quartz, sericite, pyrite, and magnetite (altered to hematite). Chalcopyrite, galena and sphalerite only occur in the Onça Deposit.

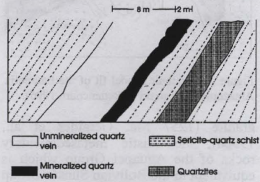

Figure 3 - Schematic W-E profile of the Onça deposit. The vein is 8 to 10 meters thick and more or less $400 \mathrm{~m}$ in length. The mineralized vein show quartz, pyrite, chalcopyrite, sphalerite and gold.

The host rocks in the Onça Deposit (Fig. 2) comprise schists and quartzites of MVSS and the ore body is a vein 8 to $10 \mathrm{~m}$ thick about $400 \mathrm{~m}$ long, with direction $\mathrm{N} 20 \mathrm{~W} / 50^{\circ} \mathrm{SW}$.

Sulfides and gold are concentrated in only two meters of hanging wall, where there are open pits and underground workings. The quartz vein carries sericite only at the contact with host rock and magnetite is absent.

\section{ANALYTIC PROCEDURES}

Three samples from the Onça deposit were chosen for $\mathrm{Pb}$ isotope analysis. The samples were crushed and sieved at 10 mesh, and the galena crystals were separated from quartz and others sulfides by hand-picking. Each sample is represented by well crystallized galena with cubic habit.

$0.2 \mathrm{~g}$ of galena were digested in hot $1.0 \mathrm{~N} \mathrm{HCl}$ during two hours and the solute was collected to separated lectures in the spectrometer. The residue was digested again in $2.5 \mathrm{~N} \mathrm{HCl}$ during two hours (with heating) and the solute was collected. The last solids were totally digested in a $9.0 \mathrm{~N} \mathrm{HCl}$. The three solutes were then gently evaporated to dryness. The materials were loaded on rhenium filaments using the standard silica gel phosphoric acid technique and analyzed in a VG 354 solid-source mass spectrometer at $1.250^{\circ} \mathrm{C}$.

The international standards for $\mathrm{Pb}$ isotopes used during the laboratory are presented in Table 1 with their respective values obtained at the CPGeo.

Table 1 - International standards of $\mathrm{Pb}$ isotopes used in CPGeo-USP.

$\begin{array}{lcccc}\text { standards } & { }^{206} \mathrm{~Pb} /{ }^{201} \mathrm{~Pb} & { }^{207} \mathrm{~Pb} /{ }^{204} \mathrm{~Pb} & { }^{208} \mathrm{~Pb} /{ }^{204} \mathrm{~Pb} \\ \text { NBS981 } & 16.9371 & 15.49175 & 36.7213 \\ \text { NBS982 } & 36.7390 & 17.19971 & 36.7449\end{array}$

Thirteen samples of galena from the Onça deposit were cut and polished with alumina for petrographic analysis. 
The polished sections were carbon coated with Bendix/CVC for microprobe analyses. The CAMECA SX50 electronic microprobe, operated by the Instituto de Geociências-UnB (Universidade de Brasilia), was used for analyses of one galena crystal chosen due to its well formed cubic habit and absence of inclusions. In the crystal fourteen points for the elements $\mathrm{Zn}, \mathrm{Pb}, \mathrm{Cu}, \mathrm{Fe}, \mathrm{Bi}, \mathrm{S}$, $\mathrm{As}, \mathrm{Ag}, \mathrm{Te}, \mathrm{Au}$ and $\mathrm{Cd}$ were analyzed, using laboratory standards. Specific conditions of the microprobe were: acceleration potential $15 \mathrm{kV}$; current 26 $\mathrm{mA}$; data collection time 5 or 10 s and bean diameter $40 \mu$.

Fluid inclusions hosted in quartz grains obtained from the same samples where the galenas crystals were collected were studied. Thin section thickness was variable, in the range of $50 \mu \mathrm{m}$ to $150 \mu \mathrm{m}$, because of the variations of the size of the quartz grains and the level of mylonitization of the grains and the influence of this in the size of the fluid inclusion.

The microthermometry data were obtained in a Linkan TMSG-600 cooling/heating stage coupled to a JENAPOL-ZEISS microscope. The calibration curve was done with specific standards of the SYNFLINC. The doublepolished sections were then analyzed by Raman spectroscopy before the second phase of microthermometry (with temperature about $600^{\circ} \mathrm{C}$ ) to avoid decrepitation of the fluid inclusions. This procedure allows the determination of the following phase transition temperatures: melting of $\mathrm{CO}_{2}\left(\mathrm{Tf}_{\mathrm{CO}_{2}}\right)$, eutectic $\left(\mathrm{T}_{\mathrm{E}}\right)$, ice melting $\left(\mathrm{Tf}_{\mathrm{H}_{2}} \mathrm{O}\right)$, melting of clathrate $\left(\mathrm{Tf}_{\mathrm{cl}}\right), \mathrm{CO}_{2}$ homogenization $\left(\mathrm{Th}_{\mathrm{CO}_{2}}\right)$ and total homogenization (Tht).

$\mathrm{Tf}_{\mathrm{CO}}$ indicates the presence of others volatils phases, $T_{E}$ can indicate dissolved cations in the aqueous phase composition of the fluids, $\mathrm{Tf}_{\mathrm{cl}}$ and $\mathrm{Tf}_{\mathrm{H}_{2} \mathrm{O}}$ provide information about the salinity of the liquid phase. $\mathrm{Th}_{\mathrm{CO}_{2}}$ indicates the density of the carbonic phase and Tht of fluids inclusions indicates a minimum trapping temperature.

The presence of $\mathrm{CO}_{2}, \mathrm{CH}_{4}, \mathrm{~N}_{2}$ and $\mathrm{H}_{2} \mathrm{~S}$ in fluids inclusions was checked using multichannel with a CCD T64000 JOBIN-YVON laser-Raman microprobe attached to a OLIMPICUS-BHS microscope and a video system. These analyses were made at the laboratory of Instituto de Geociências of UNICAMP. Specific conditions of this equipment were: $\mathrm{Ar}^{+}$source laser with a wavelength of $514.5 \mathrm{~nm}$ (green), and $50 \mathrm{~mW}$ power during $300 \mathrm{sec}$. on the sample.

\section{RESULTS AND DISCUSSION}

\section{Isotopic analyses}

The results of nine analyses of three different samples of galenas are shown in Table 2, where ${ }^{208} \mathrm{~Pb} /{ }^{204} \mathrm{~Pb}$, ${ }^{207} \mathrm{~Pb} /{ }^{204} \mathrm{~Pb}$ and ${ }^{208} \mathrm{~Pb} /{ }^{204} \mathrm{~Pb}$ ratios are separated in three different fractions obtained during the leaching $(1.0,2.5$ and $9.0 \mathrm{~N}$ of $\mathrm{HCl}$ ).

$\mathrm{Pb}$ isotope composition for galena from Onça deposit shows low variations from the core to the edge of the same crystal, and these results are not in agreement with the assumption that the crystal started its growth in the actual core and that took place essentially concentrically. When the $\mathrm{Pb}$ isotope compositions are plotted in the ${ }^{207} \mathrm{~Pb} /{ }^{204} \mathrm{~Pb} \mathrm{x}$ ${ }^{208} \mathrm{~Pb} /{ }^{204} \mathrm{~Pb}$ graphic (Fig. 4) they form a linear trend (or mixing line described by Wilton, 1991; Bierlein et al., 1996). It is possible that the crystal growth rate was not constant with time, or that the depositing solution was not changing linearly with the time. An example of a similar conditions to the Onça deposit is described by Austin \& Slawson (1961) that measured $\mathrm{Pb}$ isotopic variations in Hansonburg deposit (New Mexico) obtained in differents parts of galena crystals. The variation for ${ }^{208} \mathrm{~Pb} /{ }^{204} \mathrm{~Pb}$ and $\mathrm{for}{ }^{207} \mathrm{~Pb} /{ }^{204} \mathrm{~Pb}$ is much higher than 
Table 2 - $\mathrm{Pb}$ isotope results. Each sample was leaching with $\mathrm{HCl} 1.0 \mathrm{~N}, 2.5 \mathrm{~N}$ and 9.0 N. Following plumblumtectonics (Zartman \& Doe, 1981) this results lie on the upper Crust curve and orogeno curve of $\mathrm{Pb}$ isotope evolution.

$\begin{array}{lccc}\text { sample } & { }^{208} \mathrm{~Pb} /{ }^{204} \mathrm{~Pb} & { }^{207} \mathrm{~Pb} /{ }^{204} \mathrm{~Pb} & { }^{206} \mathrm{~Pb} /{ }^{204} \mathrm{~Pb} \\ \text { onça I }(1.0 \mathrm{~N}) & 36.646 & 15.606 & 17.585 \\ \text { onça I }(2.5 \mathrm{~N}) & 36.375 & 15.499 & 17.584 \\ \text { onça I }(9.0 \mathrm{~N}) & 36.440 & 15.523 & 17.498 \\ \text { onça II }(1.0 \mathrm{~N}) & 36.463 & 15.552 & 17.675 \\ \text { onça II }(2.5 \mathrm{~N}) & 36.403 & 15.528 & 17.657 \\ \text { onça II }(9.0 \mathrm{~N}) & 36.760 & 15.638 & 17.734 \\ \text { onça III }(1.0 \mathrm{~N}) & 36.551 & 15.562 & 17.677 \\ \text { onça III }(2.5 \mathrm{~N}) & 36.434 & 15.539 & 17.660 \\ \text { onça III }(9.0 \mathrm{~N}) & 36.433 & 15.539 & 17.668\end{array}$
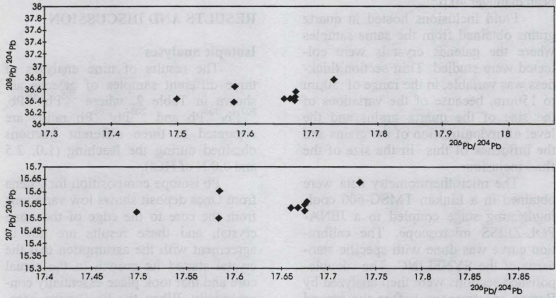

Figure 4 - The results of ${ }^{208} \mathrm{~Pb} /{ }^{204} \mathrm{~Pb}{ }^{207} \mathrm{~Pb} /{ }^{204} \mathrm{~Pb}$ display a linear trend within most of the galena crystals of Onça deposits. This trend is interpreted as due a variation in the hydrothermal composition.

the analytical error and must reflect the source region and/or the hydrothermal fluids heterogeneity that formed these mineralized veins. Hart et al. (1981) report $\mathrm{Pb}$ isotope variation within a crystal of galena with a range of $4.7 \%$ $\left({ }^{206} \mathrm{~Pb} /{ }^{204} \mathrm{~Pb}\right)$ and $2.9 \%\left({ }^{208} \mathrm{~Pb} /{ }^{204} \mathrm{~Pb}\right)$, and Doe \& Delevaux (1972) reported a $\mathrm{Pb}$ isotope variation in the Missouri district deposit as a whole in the range $5.9 \%\left({ }^{206} \mathrm{~Pb} /{ }^{204} \mathrm{~Pb}\right)$ and $2.0 \%\left({ }^{208} \mathrm{~Pb} /\right.$ ${ }^{204} \mathrm{~Pb}$ ). In this way the total range of $\mathrm{Pb}$ isotope ratios observed within the single crystals may be larger than that observed throughout the rest of the mine.

Two additional interpretations may explain changes in the isotopic composition of lead ores with continuing deposition.

The first suggests that radiogenic lead was probably collected as a contaminant by an isotopically homogeneous ore fluid when the fluids passed through the rock, intervened between 
the site of fluids that travel through a given fracture or similar permeable zone should extract relatively large quantities of radiogenic lead. Later fluids passing through the same conduits should encounter a decreasing amount of extractable radiogenic material adjacent to the fracture and thus show corresponding decreases in their radiogenic content as time progresses.

The second is based on the assumption of an isotopically inhomogeneous source for the mineralizing solutions. Thus, when the ore solution leaves the source area, the readily mobilized radiogenic lead component leaves the source in the early solutions (because of its high mobility), and the radiogenic content of the ore solutions should again decrease with increasing time (Austin \& Slawson, 1961).

Local variations in physicochemical conditions create scattered depositional sites, with some places where the content are shifted with time. Moreover, the entire favorable site was never fully permeated by ore-bearing fluids. Some areas may have been protected, as a result of sealing by early silica deposition. Other areas may have received only early solutions, and then have remained stagnant for long periods, receiving fresh ore solutions only intermittently, as early deposition would change the permeability of surrounding areas.

Although we cannot be confident about the significance of these relatively small isotopic variations within a same crystal until more detailed studies are carried out, the overall trend may be the result of either a mixing of two reservoirs or contamination by host rocks, as described by Changkakoti (1986) for the Great Bear Lake silver deposit. The high ${ }^{207} \mathrm{~Pb} /{ }^{204} \mathrm{~Pb}$ and ${ }^{208} \mathrm{~Pb} /{ }^{204} \mathrm{~Pb}$ ratios indicate a significant influence of old continental crust, i.e., $\mathrm{Pb}$ isotope ratios indicate a high $\mathrm{U} / \mathrm{Pb}$ and low $\mathrm{Th} / \mathrm{Pb}$ for the $\mathrm{Pb}$ source, such as the upper crust, before incorporation in galena crystals.

The $\mathrm{Pb}$ contamination of the fluids at the crustal stage may have taken place either when the hydrothermal solution originated from an intermediate magma (Rio Cagado suite), or from deep fluids of a regional metamorphism (Aguapei event) pervading the supracrustal hosts (MVSS). This suggests at least two or more stages for the lead isotope evolution (Stacey \& Kramers, 1975; Cummings \& Richards, 1975; Zartman \& Haines, 1988), including the Sunsás/Aguapeí orogeny.

\section{Petrography and trace elements anal- ysis}

Macroscopically, the ore of Pontes e Lacerda gold district consists mainly of pyrite, but petrographic study reveals two sulfide parageneses. The first one presents only pyrite and gold; the second presents mainly pyrite and small amounts of calcopyrite, galena, sphalerite and gold. These minerals present textures of intergrowth indicating hydrothermal source origin, characterized by the intergranular surfaces formed during the temperature decrease.

The polymetallic paragenesis was observed only in the Onça deposit and is composed of pyrite $(90 \%)$, chalcopyrite $(6 \%)$, galena $(2 \%)$ and sphalerite $(2 \%)$. Pyrite occurs as subhedrals grains intergrown with chalcopyrite. Grains of chalcopyrite, galena, sphalerite occur in the interior and at the edge of pyrite.

Galena occurs smaller as blebs in the cores, or as larger better-formed crystals at the borders of pyrite grains. It is also observed as rims involving pyrite grains or, in one case, as fracture filling of pyrite.

The analytical results of the chemical composition of the galena is presented in Table 3 . This grain was chosen due its euhedral habit and the absence of inclusions. The results of the cross section of the analyzed elements 
Table 3 - Mineral chemistry results in galena cross-section from Onça deposit $(0=$ not detected.

\begin{tabular}{|c|c|c|c|c|c|c|c|c|c|c|c|c|c|c|}
\hline ints & 1 & 2 & 3 & 4 & 5 & 6 & 7 & 8 & 9 & 10 & 11 & 12 & 13 & 14 \\
\hline lem. & $\%$ wt & $\%$ wt & $\%$ wt & $\%$ wt & $\%$ wt & $\%$ wt & $\%$ wt & $\%$ wt & $\%$ wt & $\% \mathrm{wt}$ & $\%$ wt & $\%$ wt & $\%$ wt & $\%$ wt \\
\hline n & 0 & 0.04 & 0 & 0.01 & 0.05 & 0 & 0.06 & 0.24 & 0.04 & 0.08 & 0.39 & 1.23 & 1.12 & 1.12 \\
\hline & 86.2 & 86.1 & 85.8 & 86.2 & 86.1 & 85.8 & 85.9 & 85.8 & 86.1 & 86.6 & 86.3 & 86.8 & 86.1 & 87.1 \\
\hline & 0 & 0 & 0.1 & 0.07 & 0 & 0 & 0 & 0.04 & 0 & 0 & 0 & 0 & 0 & \\
\hline & 0.03 & 0.04 & 0 & 0.03 & 0.01 & 0.01 & 0.01 & 0 & 0 & 0.31 & 0.03 & 0 & 0.05 & 0.05 \\
\hline & 0 & 0 & 0 & 0 & 0 & 0 & 0 & 0 & 0 & 0 & 0 & 0 & 0 & \\
\hline & 13 & 13 & 3.2 & 3.1 & 13.2 & 13 & 2.8 & 2.8 & & 3.1 & 13.1 & 3.2 & 13 & 13.3 \\
\hline & & 0 & 0 & 0. & 0 & & & 0 & & 0 & 0 & 0 & 0.03 & 0.03 \\
\hline & 0 & 0.11 & 0.15 & 0.04 & 0.18 & 0 & 0.02 & 0 & 0.03 & 0 & 0.05 & 0.07 & 0.05 & 0.05 \\
\hline & 0 & 0.08 & 1 & 0.05 & 0.08 & 0.04 & 0.12 & 0.08 & 0 & 0.04 & 0 & 0.04 & 0.02 & 0.02 \\
\hline & & 0 & 0 & 0 & 0.07 & 0.09 & 0 & 0.02 & 0.11 & 0.06 & 0 & 0.13 & 0.28 & 0.28 \\
\hline & & 0 & & 0 & 0 & 0.07 & .02 & 05 & 03 & 0.06 & 0.06 & 0.01 & 0.01 & 0.01 \\
\hline & 0 & & & 0 & .06 & 0.06 & & & 06 & 0 & 0 & 0 & & 0.0 \\
\hline & 0 & & & 16 & 0.27 & 0 & & & 0 & 09 & 0.02 & 0 & 0.27 & 0.27 \\
\hline total & 9.8 & 99.5 & 99.6 & 99.7 & 100 & 99.1 & 99.2 & 99.3 & 99.3 & 100 & 100 & 101 & 101 & 102 \\
\hline & at. & 6 at. & 6 at. & $\%$ at. & $\%$ at. & $\%$ at. & $\%$ at. & $\%$ at. & $\%$ at. & $\%$ at. & $\%$ at. & $\%$ at. & $\%$ at. & $\%$ at. \\
\hline $\mathrm{Zn}$ & 0 & 0.08 & 0 & 0.02 & 0.09 & 0 & 0.11 & 0.45 & 0.08 & 0.14 & 0.71 & 2.21 & 1.99 & 1.99 \\
\hline & 50.2 & 50.5 & 49.8 & 50.2 & 49.8 & 50.4 & 50.7 & 50.5 & 50.6 & 50.1 & 50 & 49.2 & 48.8 & 48.8 \\
\hline & 0 & 0 & 18 & 0. & 0 & 0 & 0 & 0.07 & 0 & 0 & & 0 & & 0 \\
\hline $\mathrm{Fe}$ & 07 & 0.08 & 0 & 07 & 0.01 & 0.02 & .02 & 0 & & 0.67 & 0.06 & & 0.1 & 0.1 \\
\hline & 0 & 0 & 0 & & 0 & 0 & 0 & 0 & 0 & 0 & 0 & 0 & & 0 \\
\hline & & & & & 19.4 & 49.3 & & 48.5 & 49 & 48.8 & 49.1 & 48.3 & & \\
\hline & & 0 & 0 & & 0 & 0 & & 0 & & 0 & 0 & 0 & & \\
\hline & 0 & & & & & 0 & & 0 & 0.03 & 0 & 0.05 & 0.07 & & \\
\hline & 0 & 0.09 & 11 & 0.0 & & 0.04 & 13 & 0.09 & 0 & 0.04 & 0 & 0.05 & 0.02 & 0.02 \\
\hline & & 0 & 0 & 0 & 0.11 & 0.14 & 0 & 0.03 & 17 & 0.09 & 0 & 0.19 & 0.41 & 0.41 \\
\hline & 0.04 & 0 & & 0 & 0 & 0.06 & 0.04 & 0.05 & .03 & 0.06 & 0.06 & 0.01 & 0.01 & 0.01 \\
\hline & 00 & & & 0 & 1.04 & 0.03 & 0.01 & & 0.04 & 0 & 0 & 0 & 0.02 & 0.02 \\
\hline & 0 & & & & 0.29 & 0 & 0.2 & 0.27 & 0 & 0.1 & 0.02 & 0 & 0.28 & 0.28 \\
\hline total & 100 & 100 & 100 & 100 & 100 & 100 & 100 & 100 & 100 & 100 & 100 & 100 & 100 & 100 \\
\hline
\end{tabular}

from the core to the edge are shown in two columns as wt $\%$ and atom $\%$ in Figure 5 and Figure 6.

Both Figures 5 and 6 show the major element zoning (lead and sulfur) and trace element zoning (antimony, silver, zinc and selenium). $\mathrm{Pb}$ and $\mathrm{S}$ composition present the same pattern in the cross-section, with increasing in wt $\%$ contents from the core to the edge and decreasing in atom \%. In the core of the crystal the $\mathrm{Pb}$ present an average of $86.0 \%$ and $\mathrm{S}$ the media of $13.1 \%$, below the stoichiometric $\mathrm{PbS}$ values $(86.6 \%$ and $13.4 \%$, respectively). Going towards the edge, the concentrations of both elements are close to $\mathrm{PbS}$ stoichiometric values. In this way, the values of $\mathrm{Pb}$ in atom \% increases, whereas for $S$ these values decrease from the core to the edge of the galena crystal.

The positive variation of $\mathrm{Pb} \%$ wt concentration from the core to the edge of galena crystal may be explained by decrease of $\mathrm{Sb}$ and $\mathrm{Ag}$ contents (Sharp \& Buseck, 1993; Sharp et al., 1990). Both elements replace $\mathrm{Pb}$ in the galena lattice, and if silver is present, to a lesser extent, the galena formed will be almost pure $\mathrm{PbS}$ (Foord et al., 1988; Pring \& Willians, 1994). The positive variation of $\mathrm{S}$ atom $\%$. values from the 
SULFUR

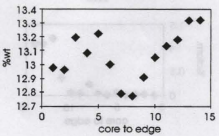

SELENIUM

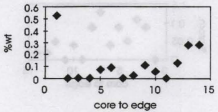

lead
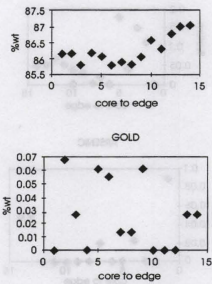

SULFUR

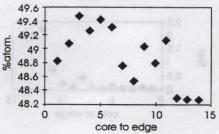

SELENIUM

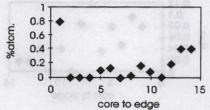

lead
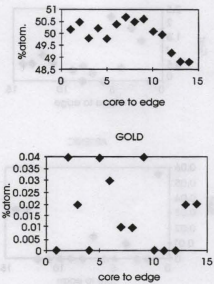

Figure 5 - Chemical variations from the core to the edge of the galena. First column graphs are in wt $\%$. Second column graphs are in atom $\%$. See text for discussion.

core to the edge of galena crystals may result from the increase of Se contents, which usually replace $\mathrm{S}$ in the $\mathrm{PbS}$ PbSe-PbTe series (Cabri et al., 1985; Liu \& Chang, 1994).

Increasing contents of $\mathrm{Zn}$ wt \% and atom $\%$ may be due to the presence of microscopic sphalerite inclusions within the grains of galena detected by the microprobe but not detected by microscopy. $\mathrm{ZnS}$ crystallizes later than $\mathrm{PbS}$, and possibly only after a decrease in temperature or due to a variable source. $\mathrm{ZnS}$ crystals are observed in 
ZINC

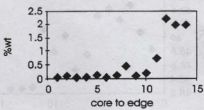

SILVER

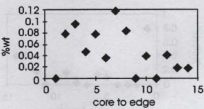

ANTIMONY

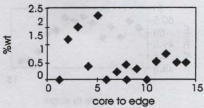

ARSENIC

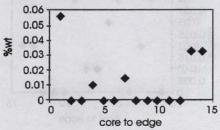

ZINC

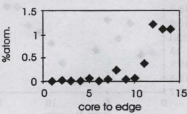

SIIVER

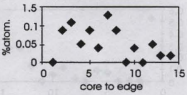

ANTIMONY

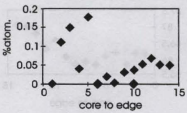

ARSENIC

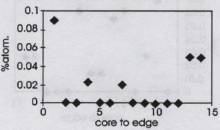

Figure 6 - Chemical variations from the core to the edge of the galena. First column graphs are in wt $\%$. Second column graphs are in atom $\%$. See text for discussion.

polished sections forming small grains or blebs within or at the edge of the pyrite crystal, suggesting that the appearence of $\mathrm{ZnS}$ is due to exsolution during a temperature decrease.

On other hand, the assumption that $\mathrm{Sb}$ and $\mathrm{Ag}$ replace $\mathrm{Pb}$ at relatively high temperatures, and that with de creasing temperature this replacement becomes difficult (as described by Newberry et al., 1991), is not convincing in this case, because the same decrease of temperature would tend to decrease the Se contents replacing S (Fig. 
4). The variation evidently resulted from progressive changes in the chemical composition of the ore-forming fluid due, as with the isotopes, to changes in the source of these solutes and/or to the changes in the host contribution. Simon et al. (1994) showed substitution of As for $\mathrm{Sb}$, and chemical zonation suggesting rapid changes in the chemistry of the mineralizing fluids of Sacarimb deposit, Romania, but these changes were not observed here (Fig. 5).

$\mathrm{Cu}, \mathrm{Fe}, \mathrm{Te}, \mathrm{Au}$ and $\mathrm{Cd}$ have no concentrate variations in the galena cross section, probably due to the constant source of the hydrothermal solute contents for these elements.

\section{Fluid inclusion study}

Fluid inclusion data were obtained by microthermometry and laser-Raman spectroscopy. Petrographic study of quartz veins (galena grains host) allowed the definition of distinct fluid patterns (types) between samples of mineralized and barren veins (see Fig. 3) of the Onça deposit.

The samples of the barren or poorly mineralized vein have white quartz, rarely yellow or pink, of milky brightness in centimetric grains with uniform extinction. The fluid inclusions observed are 20 to $40 \mu \mathrm{m}$ in size with randon three-dimensional or isolated distributions. At room temperature, the fluid inclusions have two liquid phases $\left(\mathrm{H}_{2} \mathrm{O}\right.$ and $\left.\mathrm{CO}_{2}\right)$ and $\mathrm{CO}_{2}$ gas, and the liquid/gas ratios are in the range of 0.6 to 0.01 . The main shape of these fluid inclusions is elongated and sometimes irregular .

The samples collected in the mineralized vein present colorless small crystals of strongly recrystallized quartz. These crystals have uniform extinction, and their fluid inclusions have the same characteristics as the fluid inclusions of the barren portion of the vein.

In both mineralized and barren veins secondary trails of aqueous fluid inclusions, 10 to $40 \mu \mathrm{m}$ in size, with irregular shapes and two phases (liquid and vapor) were observed. Other secondary families of small $(5$ to $10 \mu \mathrm{m})$ aqueous fluid inclusions were observed in the form of trails. Both secondary trails of fluid inclusions crosscut the quartz crystal boundaries in the mineralized portion of the vein, and these were formed apparently after three-phase fluid inclusions. These fluid inclusions were analyzed only to obtain their ice melting temperature ( $\left.\mathrm{Tf}_{\mathrm{H} 2 \mathrm{O}}\right)$, yielding values between -0.7 to $-0.3^{\circ} \mathrm{C}$, indicating very low salinity and possible meteoric origin. Petrography and fabric suggest (trail fluid inclusions crossing the mineralized and barren portion of the veins) they have no relation to the $\mathrm{min}$ eralizing solutions.

The microthermometric results of the three-phase fluid inclusions, due their possible relationship with the gold transport and deposition, are presented in Figures 7 and 8 . The barren vein three-phase fluids inclusions exhibit melting temperature of solid $\mathrm{CO}_{2}$ $\left(\mathrm{Tf}_{\mathrm{CO}_{2}}\right.$ ) between -56.5 and $-57.5^{\circ} \mathrm{C}$. The clathrate melt temperature $\left(\mathrm{Tf}_{\mathrm{cl}}\right)$ was between 7.5 e $10.5^{\circ} \mathrm{C}$. Homogenization temperature of $\mathrm{CO}_{2}\left(\mathrm{Th}_{\mathrm{CO}_{2}}\right)$ vary from 23.0 to $30.0^{\circ} \mathrm{C}$. Total homogenization temperatures (Tht) vary from 200 to $310^{\circ} \mathrm{C}$, and the homogenization may occur to a vapor phase or to a liquid phase.

In the mineralized vein the fluid inclusions present melting temperature of solid $\mathrm{CO}_{2}\left(\mathrm{Tf}_{\mathrm{CO}_{2}}\right)$ slightly above the respective $\mathrm{Tf}_{\mathrm{CO}_{2}}$ of barren portion of the vein, between -56.5 and $-57.0^{\circ} \mathrm{C}$. These fluids inclusions exhibits $\mathrm{Tf}_{\mathrm{cl}}$ between 6.0 e $10.0^{\circ} \mathrm{C}$. Homogenization temperature of $\mathrm{CO}_{2}$ vary from 24.0 to $30.0^{\circ} \mathrm{C}$. Tht occur in the range 220 to $300^{\circ} \mathrm{C}$ and also may occur either to vapor or to liquid phase.

The Raman spectra of fluid inclu- 

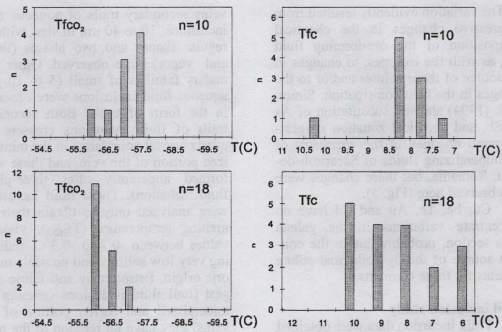

Figure 7 - Microthermometry results of fluid inclusions. (Upper) The most barren vein fluid inclusion present $\mathrm{T}_{\mathrm{fCo}}$ between -56 and $-57.5^{\circ} \mathrm{C}$ and $\mathrm{T}_{\mathrm{fe}}$ between 10.5 and $7.5^{\circ} \mathrm{C}$ (Lower). The most mineralized vein fluid inclusions present $\mathrm{T}_{\mathrm{fCO}}$ between -56 and $-57^{\circ} \mathrm{C}$ and $\mathrm{T}_{\mathrm{fc}}$ between 10.5 and $6{ }^{\circ} \mathrm{C}(\mathrm{n}=$ number of fluid inclusion).
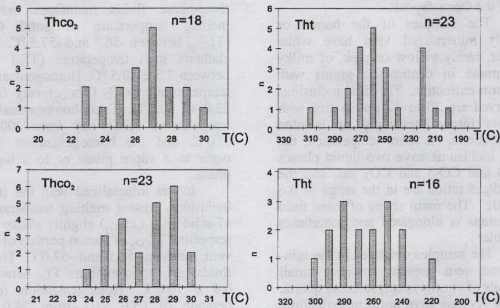

Figure 8 - Microthermomatry results of fluid inclusions. (Upper) barren vein fluid inclusion presents $\mathrm{T}_{\mathrm{bCo}}$ between 23 and $30^{\circ} \mathrm{C}$ and $\mathrm{T}_{\text {ht }}$ between 310 and $200^{\circ} \mathrm{C}$ (Lower). Mineralized vein fluid inclusions presents $\mathrm{T}_{\mathrm{hCo}}$ between 24 and $30^{\circ} \mathrm{C}$ and $\mathrm{T}_{\mathrm{ht}}$ between 300 and $220^{\circ} \mathrm{C}$ ( $\mathrm{n}=$ number of fluid inclusion). 
sions from the barren and mineralized portions of the vein are shown in Figure 9 . The main difference between the two spectra of the related fluid inclusions is the lack of $\mathrm{CH}_{4}$ peak in the fluid inclusion of the mineralized vein, in agreement with the microthermometry results, i.e., the melting temperature of solid $\mathrm{CO}_{2}$ below $-56.6^{\circ} \mathrm{C}$, which indicates the presence of other dissolved gases commonly interpreted to be $\mathrm{CH}_{4}$ and/or $\mathrm{N}_{2}$ (Burrus, 1981; Van Der Kerkhof, 1988).
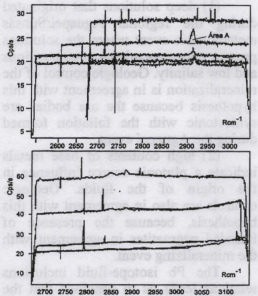

Figure 9 - Raman spectra of the fluid inclusions from the barren portion indicate the presence of $\mathrm{CO}_{2}$ and $\mathrm{CH}_{4}$ (upper) and from the mineralized portion indicate only $\mathrm{CO}_{2}$ (lower) in the volatile fases. Area A was used to calculate $\%$ mol of $\mathrm{CH}_{4}$.

Calculations of the salinity of both types of vein fluid inclusions were based on the melting points of clathrate $\left(\mathrm{CO}_{2}-\mathrm{H}_{2} \mathrm{O}-\mathrm{NaCl}\right.$ model Collins, 1979), and these scatter in the range 0.5 to 8.7 wt $\%$ equivalent of $\mathrm{NaCl}$ (Fig. 10). Salinities calculated from ice-melting temperature are expected to be higher because of the capture of a part of the water by clathrate.

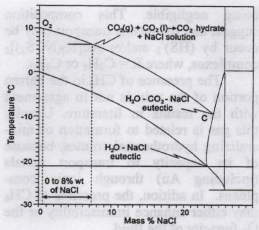

Figure 10 - According to this graph the salinity of fluid inclusions is between 0.5 and $8.7 \mathrm{wt} \%$ equivalent of $\mathrm{NaCl}$ (adapted from Collins, 1979).

The existence of one aqueous liquid phase together with two carbonic phases (one liquid and other gaseous) with different filling ratios suggests that the trapping of the hydrothermal solutes occurred at an uhomogeneous stage due probably to immiscibility of original fluid. This process is described by several authors (see experimental data by Sondergeld \& Lurcotte, 1979) as being responsible for the instability of the transported complexes of rare metals and their deposition. Therefore, the trapping temperature must be between 200 and $300^{\circ} \mathrm{C}$.

Sulfides in the ore indicate the presence of $\mathrm{S}$ in the original hydrothermal solutes, notwithstanding laser-Raman spectroscopy detected only $\mathrm{CO}_{2}$ in the composition of fluid inclusions of mineralized portion of the vein (Fig. 8). This probably resulted by the reaction of all $\mathrm{S}$ available or because very low concentrations of $\mathrm{H}_{2} \mathrm{~S}$ and $\mathrm{HS}^{-}$ would not detected by the Raman below the detection limit. In the barren portion of the vein, $\mathrm{CH}_{4}$ contents (calculated using the area A in Fig. 8) yielded average values of 8 mole $\%$ in the fluids inclusions and the $\mathrm{N}_{2}$ content being negli- 
being negligible. This composition suggest that the metals transport may be occur by (HS) 2 and/or $\mathrm{Au}\left[\mathrm{R}_{2}\left(\mathrm{NCS}_{2}\right)\right]_{2}$ complexes, where $\mathrm{R}=\mathrm{C}_{2} \mathrm{H}_{5}$ or $\mathrm{C}_{3} \mathrm{H}_{7}$.

The presence of $\mathrm{CH}_{4}$ in the barren portion of the vein is not in agreement with the results in literature. Usually this gas is related to formation of mineralizing hydrothermal solutes, because of its capacity to transport metals (including $\mathrm{Au}$ ) through ionic complexes. In adition, the presence of $\mathrm{CH}_{4}$ may either enhance immiscibility or the $\mathrm{O}_{2}$ fugacity of the fluid.

The physical continuity and interdigitation of both portions (mineralized and barren) suggest a continuous emplacement, supported by the presence of the fluid inclusions with same shape and distribution and same total temperature of homogenization. The petrographic characteristics of both portions indicate the following events events:

(1) emplacement and crystallization of all the quartz vein, with trapping of a $\mathrm{CH}_{4}$-bearing fluid inclusion in boiling process;

(2) the mineralized portion passes by a process of fracturing and cominuition of quartz, following a recrystallization of the quartz in small crystals, in which the original fluid inclusions were preserved. This cataclastic process resulted in better permeability of the rock and allowed the percolation of end-term solutes, enriched in rare metals and deposition of $\mathrm{Fe}, \mathrm{Cu}, \mathrm{Pb}$ and $\mathrm{Zn}$ sulfides and gold.

\section{CONCLUSIONS}

Petrographic study, $\mathrm{Pb}$ isotope, microprobe, microthermometry and $\mathrm{Ra}$ man spectrometry allows the interpretation of the evolution, origin and relationship between the mineralized and barren portions of the vein from the Onça gold deposit.

The $\mathrm{Pb}$ isotope-mineral chemistry allows the identification of a variable source for the $\mathrm{Pb}$ isotopes, major elements $(\mathrm{S}$ and $\mathrm{Pb})$ and trace elements ( $\mathrm{Sb}, \mathrm{Ag}, \mathrm{Zn}$ and $\mathrm{Se}$ ) with increasing or decreasing of the contents during the growth of galena crystals. The result analysis suggests that the variation may be due to the contamination of the hydrothermal solution by mixing with supracrustal rocks of MVSS.

The mineral chemistry-fluid inclusions point to two possible sources for the hydrothermal solutions:

(1) deep solutions that originated during the regional Aguapei/Sunsás metamorphic event where the solutions present aqueous-carbonic compositions and low salinity. Geologic control of the mineralization is in agreement with this hypothesis because the ore bodies are syntectonic with the foliation formed during the Aguapeí event.

(2) high contents of base metals indicate a plutonic source influence in the origin of the fluids. Geologic controls are also in agreement with this hypothesis, because the presence of intruded pegmatites in agreement with the mineralizing event.

The $\mathrm{Pb}$ isotope-fluid inclusions relations leads us to conclude that the composition of the hydrothermal solutes changes during the emplacement of the quartz veins and the growth of galena crystals. The earlier solutes had a hydrocarbon in their composition and were more radiogenic. The later solutes had base metals in the composition and were less radiogenic.

In conclusion, we suggest that the Onça gold deposit originated by hydrothermal solutions during a metamorphic event with the influence of acid plutonism. These solutes have had an important influence from the host rock for isotope compositions, as well as major and trace elements for the growth of ore-forming minerals. 


\section{ACKNOWLEDGE}

M.C. Geraldes thanks to FAPESP grants $n^{\circ} 94 / 6122-8$. This work is a contribution to IGCP 342 project.

\section{REFERENCES}

AUSTIN, C.F.; SLAWSON, W.F. (1961) Isotopic analyses of single galena crystals: a clue to history of deposition. The American Mineralogist, v.46, p.1132-1140.

BURROUS, R.C. (1981) Analysis of phase equilibria in $\mathrm{C}-\mathrm{O}-\mathrm{H}-\mathrm{S}$ fluid inclusions. In: HOLLISTER, L.S.; CRAWFORD, M.I. (eds.) Fluid inclusions: applications to petrology. Calgary, Mineralogical Association of Canada, p.39-74. (Short Course Handbook, v.6).

CABRI, L.J.; CAMPBELL, J.L.; LAFLAMME, J.H.G.; LEIGH, R.G.; MAXWELL, J.A.; SCOTT, J.D. (1985) Proton-microprobe analysis of trace elements in sulfides from some massive-sulfide deposits. The Canadian Mineralogist, v.23, p.133148.

CANNON, R.S.; PIERCE, A.P.; DELEVAUX, M.H. (1963) Lead isotope variation with growth zoning in a galena crystal. Science, v.142, n.3592, p.574-576.

COOLINS, (1979) Gas hydretes in $\mathrm{CO}_{2-}$ bearing fluid inclusionsand the use of freezing data for estimative of salinity. Economic Geology, v.74, n.6, p.1435-1444.

CROCETTI, C.A.; HOLLAND, H.D.; McKENNA, L.W. (1988) Isotopic composition of lead in galenas from the Viburnum Trend, Missouri. Economic Geology, v.83, p.55-376.

CUMMING, G.L.; RICHARDS, J.R. (1975) Ore lead isotope ratios in a continuously changing earth. Earth and Planetary Science Letters, v. 28, n. 2, p. $155-171$.
DELOULE, E.; GARIÉPY, C.; DUPRÉ, B. (1989) Metallogenesis of the Abitibi greenstone belt of Canada: a contribution from the analysis of trace lead in sulfide minerals. Canadian Journal of Earth Science, v. 26, n.1-2, p.2529-2540.

DeWOLF, C.P.; BELSHAW, N.; NIONS, R.K. (1993) A metamorphic history from micron-scale ${ }^{207} \mathrm{~Pb} /{ }^{206} \mathrm{~Pb}$ chronometry of archean monazite. Earth and Planetary Science Letters, v. 120 , n.3-4, p.207220.

DOE, B.R.; DELEVAUX, M.H. (1973) Variations in lead isotopic compositions in Mesozoic Granitic Rocks of California: a preliminary investigation. Geological Society of American Bulletin, v.84, n.11, p.35133526.

DUANE, M.J.; KRUGER, F.J.; ROBERTS, P.J.; SMITH, C.B. (1991) Pb and $\mathrm{Sr}$ isotope and origin of proterozoic base metal (fluorite) and gold deposits, Transvaal Sequence, South Africa. Economic Geology, v.86, n.7, p. 1491-1505.

ERKHOF, Van Der A.M. (1988) Phase transitions and molar volumes of $\mathrm{CO}_{2}-\mathrm{CH}_{4}-\mathrm{N}_{2}$ inclusions. Bulletin de Minéralogie, v.111, n.3-4, p.257266.

FAURE, G. (1986) Principles of isotope geology. New York, John Wiley \& Sons. 589p.

FIGUEIREDO, B.R.; GERALDES, M.C.; EBERT, H.D. (1996) Gold deposits in the Pontes e Lacerda region, SW of Amazon Craton, MT. In: CONGRESSO BRASILEIRO DE GEOLOGIA, 39., Salvador, 1996. Anais. Salvador, SBG-BA. v.7, p.195-198.

FOORD, E.E.; SHAWE, D.R. (1988) Coexisting galena, $\mathrm{PbS}$ and sulfosalts: evidence for multiple episodes of mineralization in the Round Mount and Manhattan gold districts, 
Nevada. Canadian Mineralogist, v. 26, p. 355-376.

FÖRSTER, B.; PLIMER, I.R.; BIERLEIN, F.P.; HAACK, U. (1996) Lead isotope study on hydrothermal sulfide mineralisation in the Willyama Supergrour, Olary Block, South Australia. Av stralian Journal of Earth Sciences. v.43, p.177-187.

FREI, R.; KAMBER, B.S. (1995) Single mineral $\mathrm{Pb}-\mathrm{Pb}$ dating. Earth and Planetary Science Letters, v.129, n.1-4, p. 261-268.

GERALDES, M.C.; FIGUEIREDO, B.R. (1996) A alteração hidrotermal nas rochas metavulcânicas associadas à mineralizaçăo aurífera da região de Pontes e Lacerda, MT. Geochimica Brasiliensis. In print.

GERALDES, M.C.; TOLEDO, F.; FIGUEIREDO, B.R.; TASSINARI, C.C.G. (1996a) Contribuição à geocronologia do SW do Cráton Amazônico. In: CONGRESSO BRASILEIRO DE GEOLOGIA, 39., Salvador, 1996. Anais. Salvador, SBGBA. v.6, p.554-557.

GERALDES, M.C.; FIGUEIREDO, B.R.; TASSINARI, C.C.G. (1996b) $\mathrm{K} / \mathrm{Ar}$ and $\mathrm{Pb} / \mathrm{Pb}$ isotopes studies of gold deposits in Pontes e Lacerda region, SW of Amazon Craton, Brazil. In: CONGRESSO BRASILEIRO DE GEOLOGIA, 39., Salvador, 1996. Anais. Salvador, SBG-BA. v.7, p.310-313.

GKAKOTI, A.; GHOSH, D.K.; KRSTIC, D.; GRAY, J.; MORTON, R.D. (1986) $\mathrm{Pb}$ and $\mathrm{Sr}$ isotope compositions of hydrothermal minerals from the Great Bear Lake Silver deposits, N.W.T., Canada. Economic Geology, v.81, p.739-743.

HART, S.R.; SHIMIZU, N.; SVERJENSKY, D.A. (1981) Lead isotopic zoning in galenas: an ion microprobe study of a galena crystal from the Buick Mine, Southeast Missouri. Economic Geology, v.76, n.7, p.1873-1878.

KERRICH, R. (1989) Geochemical evidence on source of fluids and solutes for shear zone hosted mesothermal gold deposit. In: BURSHAL, J.T. (ed.) Mineralization and shear zones. Canada, G.A.C. (Short Courses Notes, v.6)

LITHERLAND, M;; ANNELS, R.N.; DARBYSHIRE, D.P.F.; FLETCHER, C.J.N.; HAWKINS, M.P.; KLINK, B.A.; MITCHEL, W.I.; O'CONNORS, E.A.; PITFIELD, P.E.J.; POWER, G.; WERB, B.C. (1989) The Proterozoic eastern Bolivia and its relationship to the Andean mobile belt. Precambrian $\mathrm{Re}$ search, v.43, n.3, p.157-174.

LIU, H.; CHANG, L.L.Y. (1994) Phase relations in the system $\mathrm{PbS}-\mathrm{PbSe}$ $\mathrm{PbTe}$. Mineralogical Magazine, v. 58, n. 393, p. $567-578$.

LOPES Jr., I. (1993) Geoquímica. In MENEZES, R.G. (org.) Programa levantamentos geológicos básicos do Brasil. Pontes e Lacerda (folha SD.21-Y-C-II), Estado do Mato Grosso: texto explicativo. Brasília, CPRM/DNPM, p.75-84.

MARTARELLI, L.; FERRINI, V.; MASI, U. (1995) Trace-element evidence for the genesis of the pyrite vein deposit of Campiano (southern Tuscany, Italy). Mineralogy and Petrology, v.64, p.349-366.

MENEZES, R.G. (1993) Metalogenia. In. MENEZES, R.G. (org.) Programa levantamentos geológicos básicos do Brasil. Pontes e Lacerda (folha SD.21-Y-C-II), Estado do Mato Grosso: texto explicativo. Brasília, CPRM/DNPM, p.111-114.

MONTEIRO, H.; MACEDO, P.M.; SILVA, M.D.; MORAES, A.A.; MARCHETO, C.M.L. (1986) O greenstone belt do Alto Jauru. In: CONGRESSO BRASILEIRO DE GEOLOGIA, 34., Goiânia, 1986. Anais. Goiânia, SBG. v.2, p.630- 
646.

NEWBERRY, R.J.; EINAUDI, M.T.; EASTMAN, H.S. (1991) Zoning and genesis of the Darwin $\mathrm{Pb}-\mathrm{Zn}-\mathrm{Ag}$ Skarn deposit, California: a reinterpretation based on new data. Economic Geology, v.86, p.960-982. PEUCKER-EHRENBRINK, B.; HOFMANN, A.W.; HART, S.R. (1994) Hydrothermal lead transfer from mantle to continental crust: the role of metalliferous sediments. Earth and Planetary Science Letters, v.125, p.129-142.

PRING, A.; WILLIAMS, T.B. (1994) A HRTEM study of defects in silverdoped galena. Mineralogical Magazine, v. 58 , p. $455-459$

RAYMOND, O.L. (1996) Pyrite composition and ore genesis in the Prince Lyell copper deposit, Mt Lyell mineral field, western Tasmania, Australia. Ore Geology Reviews, v. 10, p. 231-250.

SADOWSKI, G.R.; BETTENCOURT, J.S. (1996) Mesoproterozoic tectonic correlations between eastern Laurentia and western bordes of the Amazon Craton. Precambrian Research, v.76, p. 213-228.

SAES, G.S.; FRAGOSO CESAR, A. R.S. (1996) Acresção de terrenos Mesoproterozóicos no SW da Amazônia. In: CONGRESSO BRASILEIRO DE GEOLOGIA, 39., Salvador, 1996. Anais. Salvador. SBGBA. v.6, p.69-71.

SHARP, T.G.; BUSECK, P.R. (1993) The distribuition of $\mathrm{Ag}$ and $\mathrm{Sb}$ in galena: inclusions versus solid solution. American Mineralogist, v.78, p.85-95.

SHARP, T.G.; ZHENG, N.J.; TSONG, I.S.T.; BUSSECK, P.R. (1990) Scanning tunneling microscopy of defects in Ag- and Sb-bearing galena. American Mineralogist, v.75, p.1438-1442.

SIMON, G.; ALDERTON, D.H.M.;
BLESERT, T. (1994) Arsenian nagyagite from Sacarimb, Romania: a possible new mineral species. Mineralogical Magazine, v.58, p.473478.

STACEY, J.S;; KRAMERS, J.D. (1975) Approximation of terrestrial lead isotope evolution by a two-stage model. Earth and Planetary Science Letters, v. 26, p.207-221.

SONDERGELD, C.H.; LURCOTTE, D.L. (1979) A laboratory study of mineral deposition in a boiling environment. Economic Geology, v.74, p. 109-115.

SUNDBLAD, K.; CUMMING, G.L.; KRSTIC, D. (1991) Lead isotope evidence for the formation of epithermal gold quartz veins in the Chortis Block, Nicaragua. Economic Geology, v.86, p.944-959.

TASSINARI, C.C.G.; BARBOUR, A.P.; DAITX, E.C.; SATO, K. (1990) Aplicação dos isótopos de $\mathrm{Pb}$ e $\mathrm{Sr}$ na determinação da natureza das fontes das mineralizações de chumbo do vale do Ribeira - SP e PR. In: CONGRESSO BRASILEIRO DE GEOLOGLA, 36., Natal, 1990. Anais. Natal, SBG. v.3, p.1254-1266.

WILTON, D.H.C. (1991) Metallogenic and tectonic implications of $\mathrm{Pb}$ isotope data for galena separates from the Labrador Central Mineral Belt. Economic Geology, v.86, p.17211736.

YUXUE, Z.; SHUXUN, S.; MLAOYUN, Z. (1995) The Chahe copper deposit - Its age and genesis. Chinese of Geochemistry, v.14, p.128133.

ZARTMAN, R.E; DOE, B.R. (1981) Plumbotectonics - The model. Tectonophysies, v. 75 , p. $135-162$.

ZARTMAN, R.E.; HAINES, M. (1988) The plumbotectonic model for $\mathrm{Pb}$ isotopic systematics among major terrestrial reservoirs - A case for bi- 
directional transpost. Geochimica et

Cosmochimica Acta, v.52, p.1327-

1339.

M.C.Geraldes - Instituto de Geociências, Universidade de São Paulo, Caixa Postal 11.348, CEP 05422-970, São Paulo, SP, Brasil. 